\title{
The Evaluation of Fuel Briquetts Produced from Municipal Wastes
}

\author{
Naruephat Tangmankongworakoon and Patcharee Preedasuriyachai
}

\begin{abstract}
This study aimed to turn municipal wastes from industries and households into fuel briquettes, namely coffee residue, tea residue, and fat dregs. The experiments were set up in three groups of the following mixture: Group I consisted of fat dregs and coffee residue; Group II comprised fat dregs and tea residue; Group III contained tea residue and coffee residue. The study discovered that in Group I and Group II, the ratio of 50:50 provided the highest heating value of $6,493 \mathrm{cal} / \mathrm{g}$ (Group I), and 5,727 cal/g (Group II), while in Group III, the ratio of 30:70 provided the highest heating value of $4,786 \mathrm{cal} / \mathrm{g}$. The study also discovered that the biomass wastes rendered their moisture content $(3-8 \%)$, the amount of ash $(1-5 \%)$, volatile matter (71-87\%) and fixed carbon(7-15\%).The study also found that the fuel briquettes produced from Group I and Group II had desirable characteristics to produce fuel briquettes for households since they were easily moulded, inflammable with low amount of smoke and odour while those produced from Group III were easily moulded, yet hardly inflammable with high amount of smoke. Responses from the survey indicated that briquettes made from fat dregs mixed with coffee residue were easy to ignite, left no stains on hands, burned for a long time, and had good heat output. The respondents also commented that the briquettes did not give off sparks and had less smoke and ash content than those of charcoal they normally used.
\end{abstract}

Index Terms-Coffee residue, fat dregs, fuel briquettes, municipal wastes, tea residue.

\section{INTRODUCTION}

In Thailand, several types of materials can be used as biomass energy sources, especially municipal wastes from industries and households (e.g. coffee residue, tea residue, and fat dregs), where their consumption has been increasing over the year. Especially, Coffee residue is a biomass waste of significant quantities in instant coffee manufacturing, of which 80,000 tons are produced annually in Thailand (Thailand, Ministry of Finance, Customs Department, 2007) [1], thereby creating a critical problem in waste management.

To dispose, coffee residue and tea residue are either sent to landfill sites or burned, resulting in air pollution, while fat dregs block up water pipes, causing drainage problems. Therefore, the overall waste management cost in Thailand is increasing substantially every year. To minimise the problems, those biomass wastes should be converted into solid fuel that is economical and environmentally friendly

In this study, we aimed to turn those biomass wastes into fuel briquettes from both industries and households, hoping they would generate heating value high enough to be a good

Manuscript received May 4, 2014; revised July 4, 2014

T. Naruephat and P. Patcharee are with Srinakharinwirot University, Bangkok, 10110 Thailand (e-mail: naruephat@swu.ac.th, patchareep@ swu.ac.th). alternative for Liquid Petroleum Gas (LPG) substitution, reduce community wastes, and curb Thailand's energy reliance on other countries. This study therefore assessed the physical properties of charcoal briquettes manufacture in Thailand. It also sought to assess the market potential of charcoal briquettes in the study area to establish demand for and also the willingness of potential users to substitute charcoal and firewood with the briquettes made from municipal wastes.

\section{MEthods RAw MATERIALS AND INSTRUMENTS}

To produce briquettes, we collected coffee residue, tea residue, and fat dregs from several places inside a campus of Srinakharinwirot University in Bangkok, Thailand). To prepare the ingredients, fat dregs were percolated from food scraps and washed with distilled water, left for approximately 24 hours before water was removed. Then, they were mixed with coffee residue (Group I) and with tea residue (Group II). Dehydrated by the sunlight, the remaining coffee residue and tea residue were mixed together (Group III). The ratios of all groups were established at 50:50, 60:40, and 70:30. During the mixing process, flour suspension was used as a binder to make briquettes easier to mould. The moulded briquettes were then dried under sunlight as illustrated in Fig. 1. The calorific value was determined in bomb calorimeter in accordance with ASTM D5865-12 [2] while moisture content, percentage ash content, percentage volatile matter and percentage fixed carbon were determined in a thermogravimetric analysis (TGA) in accordance with ASTM E1131-86) [3].

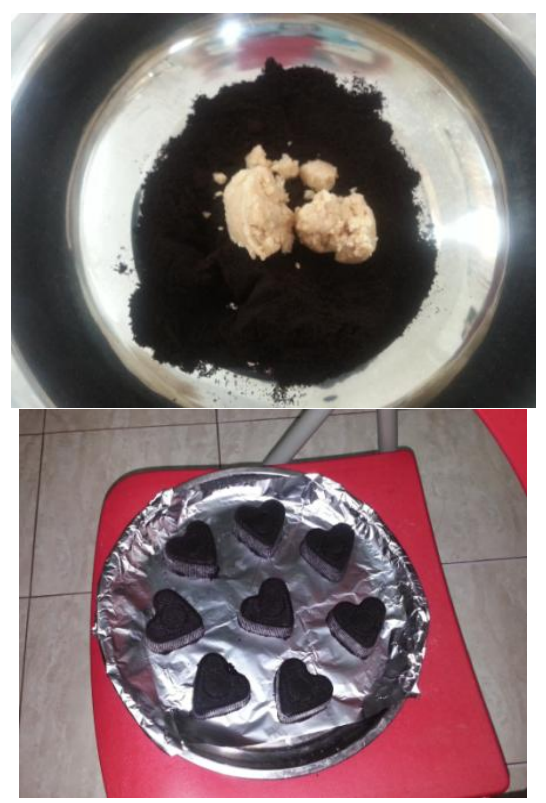

Fig. 1. Samples of briquettes in a mould form. 


\section{User Perception and Potential Market Survey}

Two kilograms of the briquettes made from fat dregs mixed with coffee residue were given to each of the 20 potential users sampled purposively from within Sakaeo province in Thailand. The potential users sampled included households and food shops of canteen for the survey. The survey was conducted through the administration of structured questionnaires a week after the distribution of the briquettes. Questions of critical importance which the potential users responded to include the effect of the burning rate of the briquettes, heat output, ease of ignition of the briquettes, burning time, convenience for usage, sparking ability and smoke generation and any other effects regarding the burning of the briquettes.

\section{RESUlTS AND DISCUSSION}

In Group I and Group II, the study showed that the less amount of coffee and tea residue added to the ingredients created better mixtures. In Group I and Group II, the study found that at the ratio of 50:50, the binder was not required, while in Group III, higher amount of binder was used since coffee residue was poorly blended with tea residue. Fig. 1 illustrates samples of briquettes after they were moulded, each with a diameter of $5 \mathrm{~cm}$.

\section{A. The Determination of Physical Properties of the Municipal Wastes}

TABLE I: THE CALORIFIC VALUES OF SOLID FUELS FROM MUNICIPAL WASTES

\begin{tabular}{ccc}
\hline \hline Sample & Ratio of biomass wastes & $\begin{array}{c}\text { Calorific value } \\
(\mathrm{cal} / \mathrm{g})\end{array}$ \\
\hline Group I & $50: 50$ & 6493 \\
Fat dregs: Coffee & $40: 60$ & 6110 \\
Group II & $30: 70$ & 5744 \\
Fat dregs: Tea & $50: 50$ & 5727 \\
& $40: 60$ & 5508 \\
Group III & $30: 70$ & 5336 \\
Tea: Coffee & $50: 50$ & 4559 \\
& $40: 60$ & 4627 \\
\hline \hline
\end{tabular}

Calorific values determined in bomb calorimeter (Leco, Model AC-350) of all groups (presented in Table I) will be discussed in this section. According to Table I, the calorific values of briquettes in Group I and Group II increased when the proportions of fat dregs were raised. However, in Group II, the lower proportions of the tea residue generated higher calorific values.

Calorific value determines the energy content of a fuel. It is the property of biomass fuel that depends on its chemical composition and moisture content. The most important fuel property is its calorific. The computed calorific value for the groupI(50:50) was 6,493 cal/g. and GroupII(50:50) was $5,727 \mathrm{cal} / \mathrm{g}$. Their energy value can produce enough heat required for household cooking and small-scale industrial cottage application.

The values of the proximate analysis (moisture content, percentage ash content, and percentage volatile matter content) were measured in a thermogravimetric analysis (Mettler Toledo) as shown in Fig. 2.

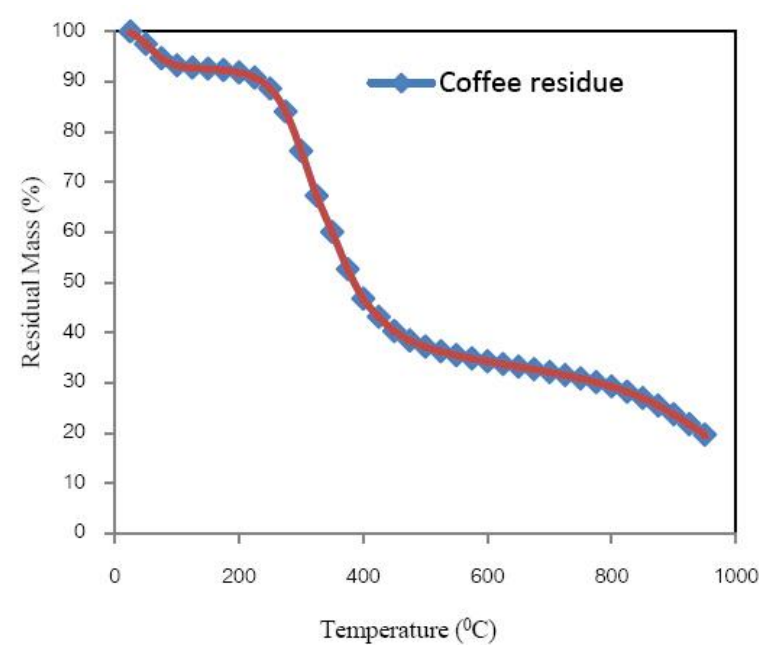

(a)

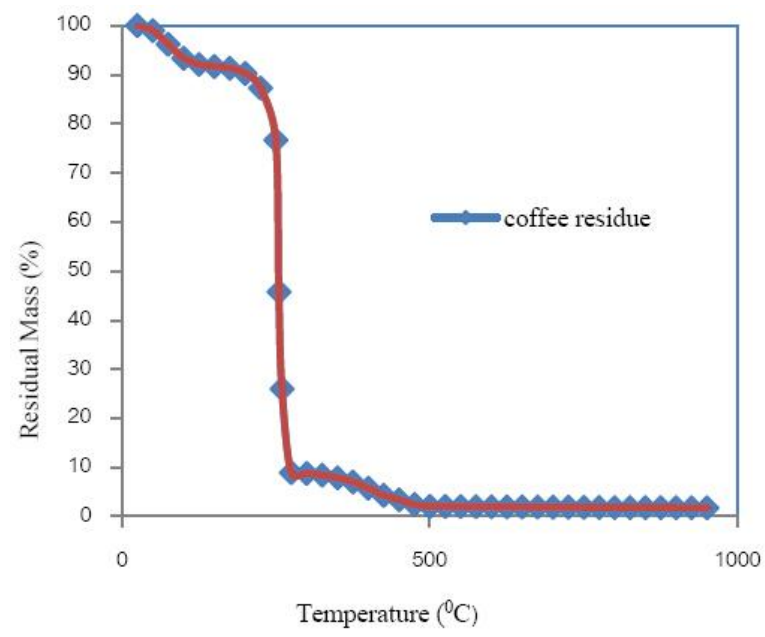

(b)

Fig. 2.Thermogravimetric analysis indicates:(a) The TGA-percentage weight remaining of coffee residue heated from $25^{\circ} \mathrm{C}$ to $950^{\circ} \mathrm{C}$ at the heating rate of $10^{\circ} \mathrm{C} / \mathrm{min}$ under $\mathrm{N}_{2} 100 \mathrm{ml} / \mathrm{min}$. (b) The TGA-percentage weight remaining of coffee residue heated from $25^{\circ} \mathrm{C}$ to $9500^{\circ} \mathrm{C}$ at the heating rate of $10^{\circ} \mathrm{C} / \mathrm{min}$ under $\mathrm{O}_{2} 100 \mathrm{ml} / \mathrm{min}$.

Based on Fig. 2a, the thermal decomposition of moisture occurred between $25{ }^{\circ} \mathrm{C}$ and $105{ }^{\circ} \mathrm{C}$ and volatile matter thermally degraded in the range of $150-5000 \mathrm{C}$. At $950^{\circ} \mathrm{C}$, the sum of fixed carbon and ash content was acquired. Concerning Fig. 2b, the TGA curve showed that coffee residue dramatically declined to become volatile matter between $200^{\circ} \mathrm{C}$ and $400{ }^{\circ} \mathrm{C}$. At $500{ }^{\circ} \mathrm{C}$, the percentage of ash content was measured. The percentage of fixed carbon was obtained by the difference between the residual mass from Fig. 2a and that from Fig. 2b. The results interpreted from Fig. $2 \mathrm{a}$ and Fig. $2 \mathrm{~b}$ were summarised in Table II.

TABLE II: THE PROXIMATE ANALYSIS OF THE MUNICIPAL

\begin{tabular}{ccccc}
\hline \hline Biomass wastes & $\begin{array}{c}\% \\
\text { Moisture }\end{array}$ & $\begin{array}{c}\% \\
\text { Ash }\end{array}$ & $\begin{array}{c}\% \\
\text { Volatile }\end{array}$ & $\begin{array}{c}\% \text { Fixed } \\
\text { carbon }\end{array}$ \\
\hline Coffee residue & 6.64 & 1.78 & 76.89 & 14.69 \\
$\begin{array}{c}\text { Tea residue } \\
\text { Fat dregs : Coffee } \\
(40: 60)\end{array}$ & 8.24 & 5.67 & 70.76 & 15.33 \\
\hline \hline
\end{tabular}




\section{B. Proximate Analysis}

The total energy needed to bring a briquette up to its pyrolytic temperature is dependent on its moistures content which affects the internal temperature within the briquette due to endothermic evaporation [4]. According to [5], moisture content is one of the main parameters that determine briquette quality. From Table II, the as-received moisture content of biomass wastes were determined to be $3-8 \%$. Those values were in a desirable range for the storability and combustibility of the briquettes as recommended by [6]. Biomass generally contains high volatile matter content of around $70 \%$ to $86 \%$ and low char content. This makes biomass a highly reactive fuel giving a faster combustion rate during the devolatisation phase than other fuels such as coal [7]. However, for the biomass wastes, the volatile content of $71-87 \%$ is considered high, The briquettes were easily ignited and their flame length increased proportionately as suggested by [7]. Ash, which is the non-combustible component of biomass wastes, was at the range of $1-5 \%$. According to [8], ash has a significant influence on the heat transfer to the surface of a fuel as well as the diffusion of oxygen to the fuel surface during char combustion. As ash is an impurity that wil not burn, fuels with low ash content are better suited for thermal utilisation than fuels with high ash content. According to [7], the higher the ash content, the lower the calorific value. The fixed carbon of the biomass wastes, defined as the percentage of carbon (solid fuel) available for char combustion after volatile matter is distilled off, were determined to be $7-15 \%$. Fixed carbon gives a rough estimate of the heating value of a fuel and acts as the main heat generator during burning [9].

\section{Respondents' Perception on the Usage of Fat Dregs and Coffee Residue for Producing Briquettes}

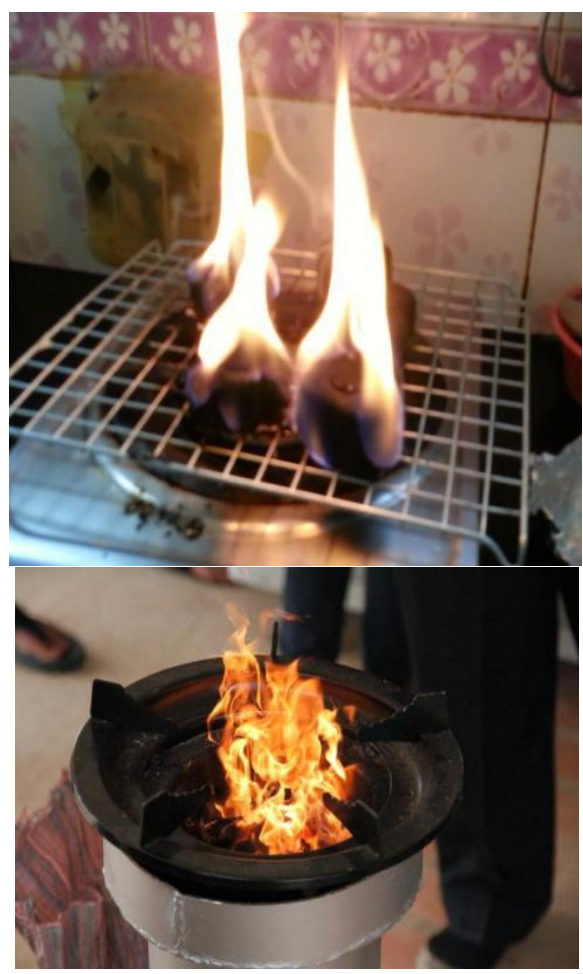

Fig. 3. Illustrates briquettes made from fat dregs mixed with coffee residue.

A survey was undertaken a week later using questionnaires to access the willingness of the potential users to use the briquettes. Twenty respondents were purposively selected from households and food shops of canteen for the survey. Responses from the survey indicated that the briquettes made from fat dregs mixed with coffee residue were easy to ignite, left no stains on hands, burned for a long time, and had good heat output as shown in Fig. 3. The respondents also commented that the briquettes did not give off sparks and had less smoke and ash content than those of charcoal they normally used. Finally, $90 \%$ of the respondents indicated their willingness to use the briquettes if the price was comparable to charcoal as shown in Table III. Although fuel briquettes were produced from coffee residue and tea residue (Group III) were easily moulded, yet hardly inflammable with high amount of smoke. As a result, further studies are required to find better methods for the production of briquettes from coffee residue and tea residue.

TABLE III: USER PERCEPTION ON USAGE OF BRIQUETTES MADE FROM FAT DREGS MIXED WITH COFFEE RESIDUE

\begin{tabular}{|c|c|c|c|}
\hline Parameter & \multicolumn{3}{|c|}{ Response(\%) } \\
\hline Usage of product & $\begin{array}{c}\text { Cooking } \\
90\end{array}$ & $\begin{array}{c}\text { Grillir } \\
10\end{array}$ & \\
\hline Ease of ignition & $\begin{array}{l}\text { Easy } \\
95\end{array}$ & $\begin{array}{c}\text { Diffic } \\
5\end{array}$ & \\
\hline convenience & $\begin{array}{c}\text { Very good } \\
40\end{array}$ & $\begin{array}{c}\text { Good } \\
60\end{array}$ & $\begin{array}{c}\text { Poor } \\
-\end{array}$ \\
\hline Heat output Intensity & $\begin{array}{l}\text { High } \\
95\end{array}$ & $\begin{array}{l}\text { Moderate } \\
5\end{array}$ & $\begin{array}{c}\text { Low } \\
-\end{array}$ \\
\hline Burning time & $\begin{array}{l}\text { Long } \\
85\end{array}$ & $\begin{array}{c}\text { Shor } \\
15\end{array}$ & \\
\hline Ash generated & $\begin{array}{l}\text { Low } \\
95\end{array}$ & $\begin{array}{c}\text { High } \\
5\end{array}$ & \\
\hline Smoke/Sparks & Yes & $\begin{array}{l}\text { No } \\
100\end{array}$ & \\
\hline Enthusiasm to use briquette & $\begin{array}{c}\text { Willing } \\
90\end{array}$ & $\begin{array}{r}\text { Not su } \\
10\end{array}$ & \\
\hline
\end{tabular}

\section{CONCLUSION}

To evaluate the types and proportion of unused wastes for producing briquettes, one needs to consider if they are suitable to the environment and the economy, as well as what types of processes and equipment that yield the best results The findings of this evaluation indicated that fuel briquettes produced from the mixture between fat dregs and coffee residue (Group I) met recommended briquette characteristics. The proximate analysis of the briquettes assessed in this study showed that briquettes produced from Group I had low moisture $(3-6 \%)$, high calorific value $(6,500 \mathrm{kcal} / \mathrm{kg})$, and low ash content $(2 \%)$. The study also found that the fuel briquettes produced from Group I and Group II had desirable characteristics to produce fuel briquettes for households since they were easily moulded, inflammable with low amount of smoke and odour while those produced from Group III were easily moulded, yet hardly inflammable with high amount of smoke. The survey also revealed that Group I could be converted into high-quality and durable solid fuel briquettes for both domestic and industrial energy production. Finally, the respondents from the survey perceived great potential in biomass briquettes for the market in the near future.

\section{ACKNOWLEDGMENT}

Special thanks goes to ILC (Innovative Learning Center) Srinakharinwirot University for financial support to this study and Scientific and Technological Research Equipment 
Centre Chulalongkorn University for giving us access to their analysis equipment and also helping with the laboratory work.

\section{REFERENCES}

[1] Thailand Ministry of Finance. The Custom Department. (December 4, 2007). Import/Export statistics. [Online]. Available: http://www.custom.go.th/statistics/statisticIndex.jsp

[2] ASTM D5865-07, Petroluem products, Libricants, and Fossil Fuels, Annual book of ASTM Standards, 2013.

[3] ASTM E1131, Standard Test Method for Composition Analysis by Thermogravimetry, American Society for Testing and Materials, 14.02-1996.

[4] C. A. Zaror and P. D. Pyle, "The pyrolysis of biomass: A general review," Sadhana Acad. Proc. Eng. Sci., vol. 5, no. 4, pp. 269-285, 1982.

[5] O. M. Aina, A. C. Adetogun, and K. A. Lyiola, "Heat energy from value-added sawdust briquettes of Alibiziazygia," Ethiopia Journal of Environmental Studies and Management, vol. 2, pp. 42-49, 2009.

[6] L. Wamukonya and B. Jenkins, "Durability and relaxation of sawdust and wheat-straw briquettes as possible fuels for Kenya," Biomass Bioenergy, vol. 8, pp. 175-179, 1995.

[7] S. V. Loo and J. Koppejan, The Handbook of Biomass Combustion and Co-firing, London: Earthscan, 2008.

[8] H. J. Kim, G. Q. Lu, I. Naruse, and J. Ohtake, "Modeling combustion characteristics of bio-coal briquettes," J. Energy Resour. Technol., vol. 123 , pp. 27-31, 2001.

[9] J. O. Akowuah, F. Kemausuor, and S. J. Mitchual, "Physico-chemical characteristics and market potential of sawdust charcoal briquette,"
International Journal of Energy and Environmental Engineering, vol. 3, no. 20, pp. 1-6, 2012.

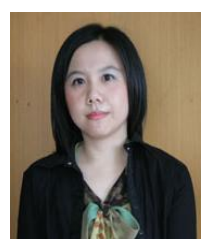

Naruephat Tangmankongworakoon was born in NakhonSawan, Thailand. In 1996, she received her bachelor of science degree in industrial chemistry from Chiangmai University, Chiangmai, Thailand. She then completed her master's and doctoral degrees in chemical technology from Chulalongkorn University, Bangkok, Thailand in 1999 and 2005.

She has served as a lecturer for the Innovative Learning Center at Srinakharinwirot University, Bangkok, Thailand for 4 years. Her research interests include but not limited to the recycle of wastes in community, alternative energy, and the pyrolysis and kinetic model of unused waste.

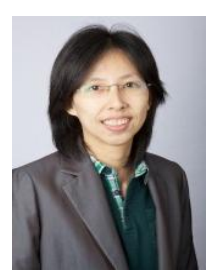

Patcharee Preedasuriyachai was born in Chiangmai, Thailand. In 2001, she received her bachelor of science degree in chemistry from Chiangmai University, Chiangmai, Thailand. She then completed her master of science degree in organic chemistry from Mahidol University, Bangkok, Thailand in 2005 and doctoral degree in petrochemistry from Chulalongkorn University, Bangkok, Thailand in 2012.

She has served as a lecturer for the Innovative Learning Center at Srinakharinwirot University, Bangkok, Thailand for 2 years. Her research interests include but not limited to the recycle of wastes in community, alternative energy, organic chemistry and petrochemistry. 